\title{
TRANSCRIPTS
}

\section{Corruption in the Pacific - a threat to cultural identity}

\begin{abstract}
This is an edited transcript of a panel discussion at a Pacific preconference of the World Journalism Education Congress (WJEC) congress in Auckland in July 2016 that relates to fundamentally crucial issues about development in the region. As the world becomes more intensely interested in what is going on in the Pacific, numerous international treaties have been signed with interest in the Pacific from the European Union, the World Bank, the Asian Development Bank in partnership with the South Pacific Forum as well as massive interest from foreign donors. How these resources are being deployed is actually crucial to successful development and many news media are trying to trace where the money goes. This is probably one of the biggest challenges, aside from global climate change and depleting fishery resources, facing the Pacific and is a threat to cultural identity. Panel convenor was Fuimaono Tuiasau of Transparency International New Zealand. Panellists were: Dr Shailendra Singh, coordinator of the University of the South Pacific journalism programme, Alexander Rheeney, editor-in-chief of the PNG Post-Courier, and Kalafi Moala, owner, publisher and editor of Taimi 'o Tonga. Associate Professor Camille Nakhid, chair of thePacific Media Centre, summed up.
\end{abstract}

Keywords: corruption, Fiji, freedom of information, journalism education, media freedom, Pacific Islands, Papua New Guinea, Tonga, transparency, Transparency International, whistleblowing

Compiled by JULIE CLEAVER

Pacific Media Centre, Auckland

\section{FUIMAONO TUIASAU:}

ULA VINAKA, Namaste, asalam walekum. Asalam walekum is an Arab greeting, and it's actually being threatened in Samoa where the church is moving to ban the practice of Muslim worship. The role of media in that country is very, very important. So I greet you in the language of the ancestors greetings. 


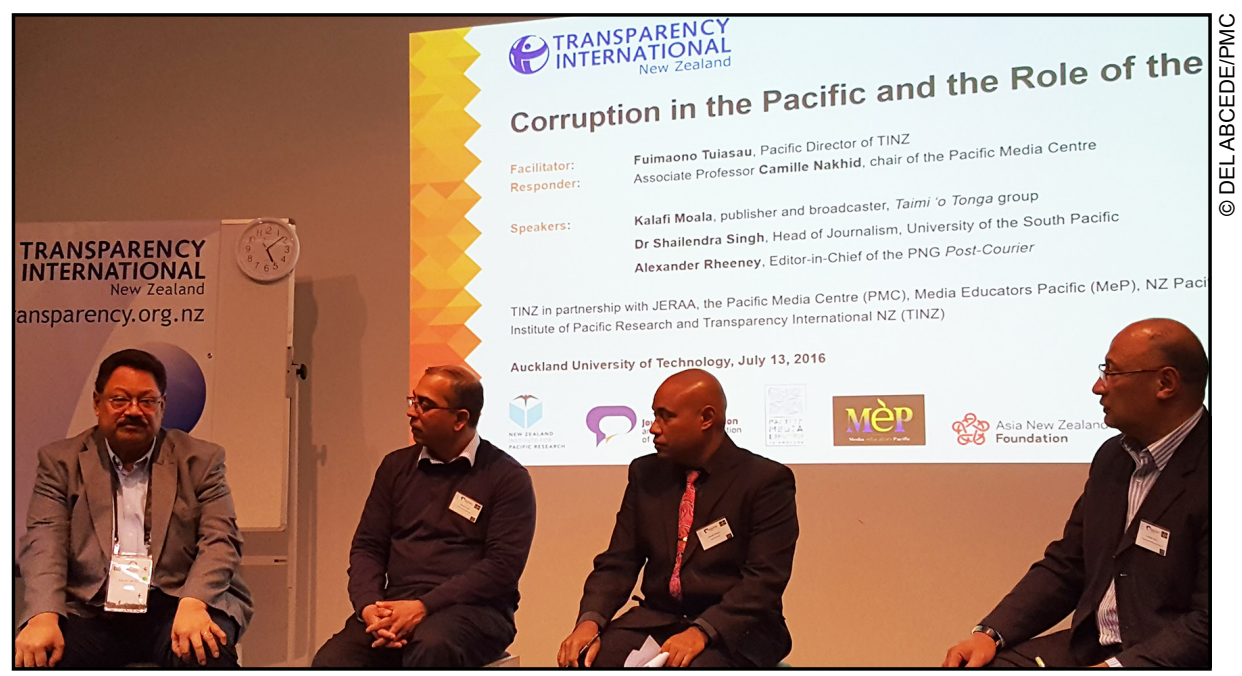

Figure 1: The Pacific corruption seminar on the eve of the World Journalism Education Congress 2016 conference in Auckland, New Zealand, in July 2016.

The session we are going to be participating in relates to something which is fundamentally crucial to development in the Pacific. As the world becomes more intensely interested in what is going on in the Pacific, numerous national treaties have been signed. There is international interest in the Pacific from the European Union, the World Bank, the Asian Development Bank, South Pacific Forum as well as massive interest from foreign donors. Where all these resources are going to is actually very crucial to the successful development and a lot of the media is trying to trace where the money goes. It is probably one of the biggest challenges, aside from global climate change and depleting fishery resources that we have, and so are threats to our cultural identity. Corruption is very much like cancer: it's got to be treated early, otherwise there's going to be massive, expensive interventions at the other end, as we see in Africa, as we see in Asia, and as we see in South America.

So Transparency International is really pleased to work with the Pacific Media Centre to bring this forum to this conference. It is important that we discuss what I think is one of the long-range issues that has to be dealt with. So you as practitioners, researchers, business owners, and journalists and lecturers and academics, your role in the future of this discussion - this debate of the Pacific - is crucial. But there are some fundamental questions: how bad is the situation? For those of us who have been paying attention to what is happening in the Pacific, two weeks ago [June 2016] a former Prime Minister of Tuvalu, Apisai Ielemia, was sent to jail for receiving backhanders from Asian businessmen (Former Tuvalu PM to serve jail term, 2016). Earlier in 2016, the former president of French Polynesia, Gaston Flosse, was sentenced to jail and fined for 
misusing his power - for essentially paying a radio station to run a campaign for a political party - he was found out and then he tried to backtrack, fast (Gonschor, 2016). But he has been caught out, essentially because the media got on to that story and exposed him and his behaviour. In 2013 Flosse was also sentenced to imprisonment as well for misuse of power (Tahiti court gives Flosse jail, 2013). The stories go on and on.

Misuse of power is essentially the essence of what corruption is about, and as recently as last week [July 2016], a 16-year-old girl was killed in the Highlands of Papua New Guinea. She posted on her Facebook a very, very strongly worded criticism of governance, particularly of some disturbances in the Highlands. But she was taken into custody by authorities, questioned about why she is criticising the government, detained for something else, and Alex Rheeney here has led the story on this. It shows that the reach of central authority, even to the highlands of Papua New Guinea, is tremendous and dangerous.

So we have some leading journalists to answer some of the questions I am going to offer, like how bad is the situation? What is the media doing about it? What are the challenges they face? Who's leading the charge? I have had the privilege of meeting these gentlemen before and discussing with them the opportunity to come and tell their stories, so it is with great pleasure that I am able to introduce to you three wise journalists. Now one of them is probably the youngest editor of any Pacific media outlet: Alexander Rheeney, who is the editor of the Post-Courier, a national newspaper in Papua New Guinea. Previously he was a communications advisor to the British Embassy in Port Moresby before heading to Australia to get a master's degree at the University of Sydney. He is very qualified to comment on the state of the media in Papua New Guinea as he is also the head of the Papua New Guinea Media Council, and they have been very vigorous in their comments and observations of how the government uses its power.

We also have an old battler from the last century, and he is still alive: Kalafi Moala. He is publisher and director of Taimi Media Network in Tonga, he is a long-time campaigner for media freedom in the Pacific region, and he has written books on the subject as well. He has observed some major changes in Tonga. One of the curious things that happened in Tonga a couple of years ago was that there is a new Standing Committee established by Parliament for combating corruption. He will make a comment on that as well.

And to bring an academic and a teaching perspective to the issues in the region, we have Dr Shailendra Singh, who is a senior lecturer and coordinator of journalism at the University of South Pacific in Suva, Fiji. Shailendra gained his doctorate at the University of Queensland. He has lectured on many issues, including media law and ethics. He holds a Master of Business Administration, and he was the former editor of The Review news magazine and is currently 
correspondent for the InterPress news service as well as other media outlets. He has a huge research interest. The one that he is really interested in looking at is corruption. So we are very, very fortunate to have someone like him with his experience and teaching abilities to bring to this discussion.

After the presentations and questions, I'm going to ask a senior staff member of Auckland University of Technology, Associate Professor Camille Nakhid, chair of the Pacific Media Centre Advisory Board, to wrap up the themes, common threads in our discussions. The first person I'm going to call on to speak is veteran Tongan media person Kalafi Moala.

\section{KALAFI MOALA:}

Thank you so much. It's so good to be here this afternoon. It's been a little over 28 years since I've been involved in starting a little newspaper called the Taimi ' $O$ Tonga, a Tongan language newspaper. When we started the newspaper we didn't know much about how to run a newspaper, and we were the first independent one that came into being in the Kingdom of Tonga. The only other newspaper was the government-owned newspaper called The Chronicle. This was a fairly difficult situation but over almost three decades of being involved in the newspaper - and more recently radio as well in Tonga-we felt that dealing with corruption was the thing to do in those first 10 years. We were trying to uncover every dirty thing that was happening within government, or involving the leaders in Tonga, or even with church leaders and so on. We were looking at Tongan society and saying there's a lot of things that are not right here and we've got to expose this as a way of bringing changes - and we did! The first things we did was uncovering the situation where Tongan passports and citizenship were being sold to Chinese overseas. That was a big thing as the government collected around US\$35 for each one for something they were doing illegally.

In 1991, there was a special parliamentary session in Tonga to discuss how they could legitimise the issuing of Tongan passports to the Chinese. And of course they were looking at Hong Kong being free from British rule at the time, going back to China and they thought, 'Well, there's a lot of Hong Kong people that want another passport for travel.' So the Tongans, being very good opportunists, thought this was a very good thing to do-let's sell the passports. It's just that they forgot that it was against the laws of Tonga to do so. Not only that, but you have to be a resident for five years and so on before you get a passport.

One of the amusing things - it's rather sad but also amusing — is that one time I came across a map. That map was given to me by a Chinese general who had come to Tonga because he wanted to go to claim his land that he had just bought in Hong Kong. So he gave me that map of a reef that is covered when it is high tide and exposed when it is low tide and somebody in Tonga decided to sub-divide this 
reef and in Hong Kong they were selling off all these different sections for a huge amount of money. And so this Chinese businessman said, 'Can you show me where my land is in Tonga?' He was quite disappointed when I told him his land is a reef, there is no such thing. But such was the beginning of exposure of practices that were going on in Tonga at the time.

When we moved into the second decade of our adventure in Tonga we felt, wow, maybe we've dealt with the major issues of corruption, we will move onto something else, but as we moved on we were finding ourselves in journalism coming across a form of corruption that was far more - the people who were exercising the practice were a lot smarter. They were planning things, and I will not go into much detail about it, but they were a lot smarter in the last ten years of our operation.

It is amazing that after almost 30 years of operation in Tonga with a very vigorous media, corruption in Tonga is worse now then it's ever been. What we did in the early days was believing that what we needed to do was bring changes or reform to our system of government. We thought all we needed to do was change the system; have our leaders and our government be held accountable; let there be good governance; let there be transparency, and then, when we did all that, there would be no corruption - there would be really nice, wonderful people.

So we did that. I personally became very involved in a pro-democracy campaign, and then in 2010 there was acceptance of a whole new system of government. The year 2014 was the first time a government came into being where an elected commoner became the Prime Minister of Tonga. Prime Minister 'Akilisi Pōhiva called me - I'm kind of fast-forwarding here — he called me after a few days in power and said Kalafi come in and be my media adviser. It was my first involvement in any kind of government job, so I went in for almost 12 months in the Prime Minister's office as his media adviser. At the end of my 12 months' contract I decided it was totally useless and a waste of time for me being involved because I found out that despite the reforms that we're doing, despite who was really in charge, corruption continued to prevail and not be dealt with. And the impact was getting worse because it was affecting the people of Tonga, and especially those that were poor and needy.

Let me take another angle here: as Fuimaono referred to, a committee was founded in the Parliament in Tonga, part of the Global Organisation of Parliamentarians Against Corruption (GOPAC). I love all of these terminologies they have- $\mathrm{UN}$ this and that, and GOPAC. The CEO of this international organisation was a gentleman by the name of Akash Maharaj. At an anti-corruption conference in Puttur, India, in 2015, he made this statement and I want to share it with you.

There's US4\$ trillion that are being siphoned off from all kinds of aid and whatever in the world today. Siphoned off through criminal activities and through corruption. There's only US\$481 billion needed to be able 
to achieve the Sustainable Development Goals (SDG). If we are able to stop this syphoning off, we would be able to solve the world's problems in terms of reduction of poverty, primary education for children and clean water, dealing with HIV and malaria and all the different things listed in the sustainable development goals. It will be many times over if we can stop the corruption.

Now small islands like Tonga and the Pacific, the impact on the poor and the impact of people, with that corruption, is extremely severe. For corruption, it doesn't matter where it happens, in an international organisation it impacts on every single human being on our planet. And so as we live in Tonga we only have a very small population of 100,000 people. I thought it was rather amusing that the first anti-corruption forum was established out of the institution of Parliament because that's where corruption is at the top. Major cases of corruption have involved parliamentarians.

The government that we have in Tonga today is a government of the people, the most democratic government that we've had, and involves people who have been campaigning for the last 30 years against corruption. But our population is broken-hearted because their hope for something different in the society has been wounded. This government has not been able to deliver. It's easy to say, 'Let's change the system'. But if you find good leaders, it doesn't matter what system they operate, they can make something out of it.

There are causes for corruption. Such questions we need to ask in the Pacific: what is the kind of corruption and what does it cause and who is it impacting on? How is the media operating in the Pacific? In every aspect of our society, at least in Tonga, we see the effects of corruption.

I need to tell you a story, then I'll sit down — good Pacific Islanders must tell a story. In a little village there are two women sitting there and they are watching the river flowing down and they are just talking stories, like most Pacific Island women do. And as they are telling stories they look out and see something that is floating down the river. They look closer and one of the ladies says, 'Oh no! That is a baby in a coconut basket!' Both of them, shocked by this sight, jump into the river to rescue this baby. As they dragged it out and onto the river bank where they were sitting, one of the ladies noticed there was another basket flowing down the river. She said, 'You go and rescue that one and I'll take care of this one.' So she jumped in and rescued that baby. Within a few minutes, they saw all these baskets flowing down the river with babies. They rushed to tell the village people, saying, 'Sometimes we have an overflow of fish, but now we have a big overflow of babies flowing down the river.' Someone suggested they make contact with the United Nations - maybe they needed to create a baby rescuing operation for the beach, as all these babies were flowing down the river. 
No one ever thought to go up river and check where these babies were coming from and who was throwing them into the river. One of those ladies thought, 'You wait here, I'm going to go upstream and find out who is throwing those babies - we've got to put a stop to that.'

I'm throwing up this story as an illustration. We've got to get to the cause of this, we've got to get to the source and we've got to deal with it. Until we deal with it, we are going to have corruption as part of our life and society every single decade of our lives. We cannot just deal with the impact of corruption, we cannot just put a bandage over it and form committees - there are too many committees! They are doing nothing. We've got to go up there are see who is throwing those babies into the river and deal with it. Thank you very much.

\section{FUIMAONO TUISAU:}

Thank you Kalafi. While you were talking, I thought about that saying from Abraham Lincoln: 'most people can deal with adversity, but if you want to test a man's character, give him money, stand back, and watch what they do with it.' I think Kalafi's recent experience with the parliamentary office is a sad testament to that. Just so you know that New Zealand is not escaping from any of this-New Zealand is ranked fourth in the world on the anti-corruption index. We are the third in the world on the justice survey, our Parliament ranks very highly. And in Forbes magazine last year, New Zealand was called the second best country to do business with, after Denmark and ahead of Norway. So we've got many things to be thankful for. However, our reputation, our character is constantly being challenged and is at risk - and there are many, as we have seen recently.

With the Panama Papers we have seen that New Zealand is a tax haven, but they don't call it that, they call it a tax negotiating state (Chenoweth, 2016). We know that there are more than 300 secret trusts set up in New Zealand with money that has come from overseas, a lot of it from leaders, corporates and rich families. The recent John Shewan (2016) report indicated that New Zealand essentially does not know what the real source of that money is. Is it from corrupt leaders from overseas? Or corporates who have avoided paying tax in their own countries? For this session here my question is: how much of this is coming from corruption from third world leaders, corporates from the first world, and that question is yet to be answered.

In the beginning of last week [July 2016] the auditor-general released a report on the silent sheep deal. This is a deal the New Zealand government has started entering into with a Saudi Arabian business man where live sheep were exported to Saudi Arabia. The deal wasn't actually formalised but then on top of that there was a cover up, and then the Saudi businessman threatened the New Zealand government with legal action and a whole lot of other things. He had no legal basis that would support anything that he was alleging. But over the 
period of 12 months he received NZ\$10 million from the New Zealand government, essentially to make him go away.

Now that $\$ 10$ million has been characterised as 'I can make him go away'. Or in the new language of anti-corruption, a facilitation payment. I facilitate you to stop hassling me. And the minister responsible for that transaction has now been found to have misreported those transactions in Parliament, so watch this space. Again both this and the Panama Papers is a result of media scrutiny, very clever people looking at the numbers. And there's local corruption here. I know a very clever accountant and he will tell you, one of the biggest challenges for Auckland businesses at the moment is the massive operation from people all over the world as there's a slippery standard at which people operate. Building inspectors turn up to inspect buildings, restaurant health and safety inspectors go to food malls and courts and restaurants and they're offered all sorts of things. The chief executive of the Auckland Council has reported that in his annual report to the council, and there have been a number of prosecutions. So my message to you as an audience of Pacific people is that New Zealand has got a long way to go as well. We've got fantastic systems but they're only good if we can detect the issues early on. Again the media is very, very important for exposing these practices. Now let me introduce to you Shailendra Singh.

\section{DR SHAILENDRA SINGH:}

My presentation is going to be in two parts. First, I will set the Fiji national context, which is quite tricky and difficult and then I will speak on the media aspect - the challenges the media faces. It's hardly a secret that Fiji has been plagued by corruption since its independence in 1970, with little improvement in sight for what is a really complex and entrenched problem. The country's consistently below average ranking on international corruption measures have indicated poor performance for many decades now. Freedom House's 2015 (Discarding democracy, 2015) report stated: 'Corruption is a serious problem in Fiji'. This is undeniably true. Persistent corruption is hampering the country's efforts to escape the poverty trap. We have 29 percent of our population still caught in this trap, partly due to corruption. Fiji has seen it all, from grand scale to petty corruption. Among the worst is government and public service malfeasance. Corruption is blamed also for Fiji's debilitating 'coup culture'-we've had four coups in the last 25 years.

This has stunted growth to a meagre 2 percent in the last 25 years which is simply not enough for job construction or any kind of stable and consistent development. The 1987 and 2000 coups were couched in indigenous rights rhetoric. In reality, the coups were orchestrated by a corrupt, political and business cabal. The National Bank of Fiji scandals were a product of the 1987 coups. And the state bank lost F\$372 million. When the National Bank of Fiji story broke, the 
Finance Minister said - and I'm not joking here- 'It's water under the bridge'. Understandably so, because his cronies and colleagues were knee-deep in the scandal. One of the problems is that politicians are not taking corruption or Fiji's lack of development in a serious enough manner. Fiji's 2006 coup - the fourth coup - was staged by then military commander Voreqe Bainimarama. This was a bit of a reversal: the previous three coups were executed to mask or hide corruption. The 2006 coup was executed in the name of a cleanup campaign. Because the Fiji population was so fed up with the past corrupt administrations, they lapped up Bainimarama's oratory about a cleanup campaign received quite a bit of support from sections of the general population, and even the media.

Fiji's corruption score had dropped negatively under the pro-indigenous Laisenia Qarase government. This government was ousted by Bainimarama for its alleged racist stance and discriminatory policies. Under Bainimarama's watch there was a noticeable, 20 percent positive upswing. The Bainimarama administration set up the Fiji Independent Commission against Corruption (FICAC) - first for the country. In 2013 alone, this commission received 10,000 complaints. So that's a measure of the scale of the problem in Fiji, at last in some respects. The anti-corruption platform of the Bainimarama government was a winner in the 2014 general election, the first since the 2006 coup. His FijiFirst party won a majority in the elections, so coup leader Bainimarama became the elected prime minister, amid much expectation. However, the opposition frequently accuses the Bainamarama government of failing to live up to its own ideals. It pointed to the seven year delay when releasing annual auditor-general reports. In previous years the auditor-general reports were a testament to the sleaze in the civil service. It made fascinating reading, year after year.

The government has also reduced the number of parliamentary sittings, which the opposition seesas a big problem with regards to accountability. In addition, the government has removed the Opposition Leader as chair of the Public Accounts Committee and replaced him with an allegedly pro government MP. In the eyes of critics, these moves contradict and also compromise the government's expressed anti-corruption stance. So the context is quite complex and quite paradoxical also. From a journalistic perspective, it's even more challenging.

To analyse and report corruption systematically, you need experienced reporters with some investigative skills who are given the time and space to operate. This is sorely lacking in Fiji. For my PhD research in 2012, I did a survey of the state of journalism in Fiji and what I found was that 32 percent of the Fiji journalist corps had less than three year's experience. This is well below the global average. And a staggering 55 percent had less than six year's experience. However, the journalists who have more than six years of experience are not out in the front line doing reporting, they were actually running newsrooms. So experienced journalists are running newsrooms - managing the newsroom - they 
are not out there reporting. People who are out there reporting have on average less than three year's experience. Only 49 percent had any form of academic qualifications.

Because the news media in Fiji is not competitive salary-wise, reporters do not hang around for long. They leave for greener pastures on a consistent basis. So there is a perpetual problem with staff turnover and newsroom capacity. Lack of journalistic will is another problem, and this can be linked to two variables: media ownership structure and also punitive legislation. Editors and publishers face stiff fines and jail time for breaching the vaguely worded Fiji Media Industry Development Decree 2010 (Media Industry, 2010). This decree has criminalised what we once considered ethical breaches. If you put one foot wrong you could end up in jail or face a really stiff fine, or both. So this can have a chilling effect on reporting and also lead to self-censorship.

While media have met their capacity to investigate courageously with published official audits and also reports that might 'fall off a truck'. But media legislation will make even this difficult. Under the media decree, the government regulator can enforce source disclosure by searching media premises and also confiscating material. While cases concerning state corruption are exempt, the disclosure provisions is a disincentive for whistleblowing and this is because in any swoop or raid, the identity of confidential sources could be at risk. The good news for Fiji is that the Attorney-General has promised to table the Freedom of Information Bill in the next sitting of Parliament. The bad news is that the strict media legislation is largely to stay. This takes the teeth out of the freedom of information law, if it is implemented.

With media ownership, after 2010 the decree required 90 percent local equity. What this has done is put Fiji's print media into the hands of two local conglomerates. These entities, with major stakes in various sectors of the economy would rely, to a certain extent, favourable government policies for a good return on their investment. Also the profit from the media business is negligible in comparison to the investments in other sectors of the economy. So this is the key question: will these conglomerates compromise their greater investments by allowing the media arm of the business to criticise the government at will? This is another way, perhaps, of silencing the media, at least in some respects.

Geopolitics and political correctness are further obstacles to reporting corruption. Recently David Cameron, of Panama Papers fame, was overheard telling the Queen that fantastically corrupt countries had been invited to a conference. So there was a media furore, with some saying that the occasion wasn't right for such an insulting comments. But the occasion was a summit on global corruption. So a jokey media chose to focus on the humor of the diplomatic gaff, rather than on the serious side. I bring this up because similarly, Australia and New Zealand have been accused of turning a blind eye on Fiji and this is due to geopolitical considerations 
and also diplomatic niceties. If all this wasn't enough, some regional leaders have evolved to develop really thick skin, so the media can name them, yes, but they can't shame them. Plus some of our populations can be quite forgiving because of culture, Christianity and also a cargo cult mentality. So what happens is that corrupt politicians keep returning, they keep being voted back, they keep turning up like a bad coin. The scales of justice are uneven - only the small fry face the brunt of the law, and the sharks get favourable treatment, or they get away scot-free.

To end on a rather sombre note, the odds are stacked against reporting corruption in a sustainable and effective manner. Media is arguably more a nuisance than a deterrent, I think Kalafi Moala said that. Which is not to say that media have not done a marvelous job despite serious resource constraints, and also a treacherous terrain.

\section{ALEXANDER RHEENEY:}

Maybe I'll just give some context to the mention of the Facebook post where a girl was actually arrested by police in Papua New Guinea over the posting. It was actually run in The National newspaper, which is the rival daily in Papua New Guinea. There is a lot of concern now when authorities are actually reacting to social media postings, when all Papua New Guineans know freedom of expression is enshrined in the PNG constitution. Just to give you a state of play in terms of media press in Papua New Guinea, there's about 13 to 15 mainstream media organisations in the country. Four newspapers, five radio stations, three national television stations and online news service Loop PNG run by Digicel. Now in terms of the breakdown, the government owns two of those radio stations - FM1 and Radio NBC - as well as two television stations, EM TV and NBC. Now for the newspapers, three newspapers are privately owned: I work for one of the PNG Post Courier, The National [owned by Rimbunan Hijau, a Malaysian logging company], and the Sunday Chronicle, which comes out on a weekly basis.

And then there's a couple of radio stations that are locally owned - the major ones are Fiji-owned by Pacific Communications, and PNG FM, which has been around for a long time now. We have a new online news service now which has basically changed the whole media landscape in Papua New Guinea. Loop PNG looks for strategies to capitalise on young Papua New Guineans who are very, very interactive on social media right now. We had some figures today of about 350,000 Papua New Guineans who interact on Facebook. So there is a very energised young population wanting to engage in conversation, and Loop PNG has seen the potential and they have actually invested in that. I can only say, speaking from a mainstream media perspective, Loop PNG and Digicel coming into PNG are a blessing in disguise. Of course it gives competition to mainstream media, to the Post-Courier, because you know global trends indicate that Papua 
New Guineans will make a shift from opening the daily paper in the morning to checking their smart phones. But I don't see that happening in the next, say, 10 to 20 years. Because firstly, internet penetration still remains at about 2 percent nationally. And secondly, the literacy rate in PNG is somewhere around between 50 to 60 percent, so we still have a large number of Papua New Guineans who can't read and write. Consequently they cannot appreciate the extra features and the joys of using smart phones.

In terms of covering corruption in Papua New Guinea, you just have to look at the Transparency International Corruption Perception Index (Corruption perceptions, n.d.). Last year [2015], Papua New Guinea scored 139 on the list. Sadly, there was sort of some improvement when the Peter O'Neill government came into office, and then there was a drop again in the figures, so things haven't been looking very rosy in Papua New Guinea. There was a lot of optimism by Papua New Guineans when the O'Neill government came into office that there would be a change in culture in terms of how politicians behave themselves; in terms of how politicians are transparent in their dealings; in terms of how politicians hold themselves accountable to the constituency. I can say that from my own perspective, the performance of the O'Neill government over four years now hasn't been any different from the Sir Michael Somare government in terms of its dealings and its ability to allow Papua New Guineans to their representatives to hold government accountable in Parliament. And I think one of the classic examples I can think of is last year in November [2015] when the government basically bulldozed the national budget without allowing Parliament to dissect and to debate the money plan for this year. So those are some of the examples of government refusing to allow the checks and balances that are in place in PNG - refusing to allow institutions like Parliament to hold executive government accountable. And sadly, the O'Neill government in my perspective is going down the same path as the Somare government had gone down 10 years ago. And it doesn't augur well for Papua New Guineans because a lot of our development challenges are well known. We've got some of the worst infant mortality rates in the world; we've got an HIV Aids epidemic that needs to be tackled immediately; we've got a tuberculosis outbreak that's just about getting to the national capital of Port Moresby. That has not all been addressed because basically government has failed to allow other institutions of state such as National Parliament to debate those issues and play the role that it's supposed to play. One of the biggest challenges now is the Prime Minister's own corruption proceedings against him when police wanted to take him in for questioning in 2014 (Papua New Guinea prime minister served, 2014). The matter has dragged on for a while now. From my own perspective covering the issue, there has never been a single matter that has never been so stressful for a journalist, because the matter relating to the arrest of the Prime Minister has basically put 
a lot of pressure on local journalists to report without fear or favour. I can tell you that - wearing my Media Council of Papua New Guinea hat, I've heard reports of journalists being warned, being threatened by personalities, in terms of withdrawing advertising - if you get to report on this or if you get to report on that. So from my perspective as a journalist I would want this whole case to go away so that we can get back to the normal business of covering issues that matter for ordinary Papua New Guineans. Unfortunately the matter has dragged on since October 2014. The matter has been in court. I've sent an email to the Prime Minister's press secretary asking for a breakdown of how much it's costing the tax payers in terms of the legal bills. The press secretary replied, 'I'll get back to you.' It's been two months and I haven't had a response yet.

Journalists now need to start asking the hard questions: how much is this whole situation costing ordinary Papua New Guineans? How much does it mean in terms of Papua New Guineans missing out on another basic service? Papua New Guinea is going through an economic crisis at the moment with low global community prices. The government is facing a serious cash flow problem, so cash is hard to find at the moment. And then we have the legal proceedings that are currently on full concerning the Prime Minister. So the latest twist to this whole saga was the Supreme Court making a decision on a court application to actually record Parliament. So the Supreme Court has ruled that the decision by the Acting Speaker to adjourn Parliament to August 2016 is unconstitutional and the court has now ruled Parliament must be recalled within five days.

You would love to work as a journalist in Papua New Guinea because we have some of the best stories in the world as politicians can pull something out of the bag that no other politician can do. I just met a brother/colleague from Vanuatu and I was just telling him this morning that I think the story coming out from Vanuatu on the 11 politicians getting locked up for corruption was something that's never happened in PNG (Vanuatu court sentences, 2015). We would definitely want to go down that path!

In terms of journalists holding leaders accountable - it's a big task, it's a really big challenge. And you know, journalists continue to be the meat in the sandwich on both sides: we've got Papua New Guineans who are so passionate about holding government accountable on one side, and we've got leaders who basically want us to move on and cover other issues. So where do we go? So those are the challenges that my colleagues are facing at the moment. Going into the future, I reckon social media is a blessing in disguise, while I acknowledge the fact that it is a threat to mainstream media. In Papua New Guinea, I've always told colleagues that as journalist you are not only defenders of truth, you are defenders of freedom of expression. You have to defend Papua New Guineans' right to express themselves, as journalists. So there have been some indications from government that they are trying to bring down a Media Tribunal Bill, 
to 'regulate' the media industry - therefore we would be going down the same path Fiji has taken. However, the plans were shelved in 2015, thankfully. But being shelved doesn't necessarily mean being put away for good. Reporting on corruption, fighting corruption from a media perspective, is always a work in progress in Papua New Guinea.

FUIMAONO TUIASAU: If you can all turn off your internal dialogue I'm going to jump straight into questions. I'm going to ask Alex a follow-up question: we've seen some terrible pictures of students being locked up and badly treated by police for their plans to march in Parliament (Matasororo, 2016). Those stories are again coming from the media. So do you have a comment on how this has been handled by the media networks?

ALEXANDER RHEENEY: The shooting of unarmed demonstrators from the University of Papua New Guinea on 8 June 2016 was a very unfortunate incident. It was unwarranted, but basically the police decided to open fire outside the gates of the university when students wanted to go to Parliament to give a petition. And this was after five weeks of protesting in an attempt to force Prime Minister Peter O'Neill to resign and step down from office. It was the government actually, so consequently the police opened fire. Close to 30 people were wounded - there were four who were seriously injured and who were hospitalised. So I think the Supreme Court's decision yesterday, it's a pressure off (PNG Supreme Court orders PM to face no-confidence vote, 2016). You will see most Papua New Guineans will give a sigh of relief knowing the Supreme Court ruled along those lines. Because ultimately national Parliament should make a decision when a country is in crisis.

FUIMAONO TUIASAU: Kalafi, last month there was a story that came out of Tonga about a young girl - a journalist — who asked the Prime Minister some very assertive questions about education and other issues, and as a result of that the Prime Minister tried to get her de-registered as a journalist. Can you explain what happened there, and what transpired?

KALAFI MOALA: She's not a young girl, she's one of Tonga's most experienced journalists, Viola Ulukai, and she has been working in the government media —as you know the biggest media in Tonga (with television, radio AM and FM) is the government. And she's been actually the editor of the news section of the government media. But in interviews with Prime Minister 'Akilisi Pōhiva, she started probing quite deeply into issues and it offended the prime minister, and it offended his supporters. So there were moves immediately to have her resign (Moala, 2016). They even instructed from the Prime Minister's Office for the manager to 
kick her out. And all sorts of pressure came on her. Of course there were a number of journalists who stood with her and encouraged her.

However, that just shows you this [sort of thing] is coming from a government now that had for so many years been campaigning for media freedom and allowing criticism to be a normal thing in Tongan society - so that was a shock. Right now, of course, she has refused to resign, and the government has kind of backed off because there were a lot of pressures from media from overseas on that. But there are quite a number of moves like this from this government. I think if it had been another government it would have been different. People are kind of shocked, and they are asking, 'How can this government; a democratic government, a government which campaigned for reform, how can they do these things?' And it brings me back to some of the things that I said: good leadership, it's not so much a system, you can change a system, but you've got to change people. The leaders, they're the ones who have got to practise good governance. They're the ones who have to practise transparency and accountability. And if they're not, you could have a system and a constitution and everything, and it won't make a difference.

FUIMAONO TUIASAU: I'm just going to open it to the floor now: are there any questions, Penny?

PENNY BRIGHT (Auckland local government anti-neoliberalism and anti-corruption activist): Kalafi, I can tell you who's putting the babies in the basket and sending them down the river. I've been to five international anti-corruption conferences, and I went to the Transparency International Conference in 2010, the figure that blew my mind was that the global market was seen as 14 trillion dollars, of which two and a half trillion is said to be lost in crime and corruption. I have exactly the same question: two and a half trillion dollars to feed, clothe and help poor people. Then what hit me like a sledge hammer is that Transparency International were not looking at the underpinning private model, they were looking at the process - were contracts being done in the correct way, blah blah. But nobody was actually asking, 'Hang on a minute, we've had 30 years of this "public is bad private is good", where was that substantiated before it was forced upon the peoples of the world, where has it been substantiated since? Then I realised that those fighting privatisation and those fighting corruption need to work more closely together, because I may be one of the only people saying this, but the root cause of corruption is privatisation.

In order to find out, to do the cost effectiveness, you need to find out where is the money going. New Zealand's Public Records Act is a piece of legislation that has transformed transparency in this country, but most people haven't even heard of it. That's the thing, if you have full public records available for public 
scrutiny, then you can follow the dot, which is the first step to helping to fight corruption all over the world. So I'm just wondering, does Tonga have a public records act?

KALAFI MOALA: Well, as a journalist one of the things I've always thought about and taught even our journalists in terms of investigation of corruption, is that you follow the money. You find out where the money is flowing and [when] you follow that it usually ends up in the hands of someone who is not honest and it has proven over the years, time and time again, that that's right.

FUIMAONO TUIASAU: Just as a follow up question: is it true that the current leaders, maybe for the last 30 or 40 years in Tonga, have all come from three schools in Nuku'alofa and these three schools, and no other schools, have national leaders. It's almost like a, well I'd say it's an old boys network, but there's also some old girls there too. I've heard that rumour several times, and I'm wondering if there's some basis for it.

KALAFI MOALA: The first school in the Pacific Islands to build a college just celebrated 150 years, Tupou College. It was the first school established in Tonga and in the Pacific Islands. And it was the only college for so many years, and so the late King Tupou V had to go forth when his brother was prime minister, so the majority of leaders in the 1950s, 1960s, 1970s went to that college. The second one is the government college called Tonga College, established about 1880. And the third one was actually founded much later in 1947, which is Tonga High School. This is a kind of an elite school where they have exams of all the primary schools and they take the top people and put them into this high school, and right now in Tonga, most of the leaders that are emerging come out of that school, so in a sense that's true.

QUESTION FROM AUDIENCE: Question to Kalafi regarding the suspension of journalist Viola Ulukai by the Tonga Broadcasting Commission. Given your involvement with and knowledge of local politics, do you have any sympathy for 'Akilisi Pōhiva's fairly obvious feelings that in fact she's part of a bid to constantly undermine him. Would you have any sympathy for the prime minister on this one? And that she's using her position to attack him?

KALAFI MOALA: That's a very, very good question because when you look at politics in Tonga over the past 30 years, it's not so much about what you believe, or what you advocate, it's about which side you are part of. And so even the prodemocracy movement became more of a side to belong to, with 'Akilisi Pōhiva being the leader, rather than what they really believed. And my involvement, 
I mean I was in jail together with 'Akilisi Pōhiva in 1966. But my recent involvement with them really brought it home to me that politics in Tonga has nothing to do with your doctorate or your beliefs, it's which side you are part of. In other words, if you are critical of 'Akilisi Pōhiva you must be part of the other side, and if you are critical of the royal family and the nobility, you must be part of the other side. However, the reality of that in Tonga is that it's not true - it's not true at all.

I think what the Tongan population is really going for, they want something that is based on substance and, of course, it's proven that with this government, despite the fact that 'Akilisi himself has been having very good rhetoric on all of that anti-corruption, the first thing he did when he got into office was appoint his son to be his personal assistant. The second thing he did was bring his son out of Fiji to be the second adviser with his friend on education on Tonga, to reform education. So I can go all afternoon with a whole bunch of things that go against what he has done. Sympathies with him? Yes. As a critic and an opposition leader? Terrible, terrible governor.

And I told him [when he first became prime minister], 'Your problem is going to be this: you have an opposition mentality. But you need to shift that mentality to a governing mentality.' And he hasn't done that, he's done it worse. He started investigating his own people, and sniffing them out for corruption, but that's the battle that this government is going through. And there is more corruption that has been uncovered during his time in just the last two years - he's hardly been there two years - than in previous governments.

QUESTION FROM AUDIENCE: Give us some help, and I mean that. Because what you're describing could also be a reflection of what's happening around the whole of the Pacific. So where do we go with this? How are things going to change?

In fact, this leads into the same question I was going to ask Shailendra: you're teaching student journalists. What is the picture looking like? In fact, you told me you're teaching 200 journalism students?

DR SHAILENDRA SINGH: There's about 100 students. We have about 100 new recruits. And we have a three-year programme and all that. It's a bit tricky because the legislation covers journalism students, also students are not examined. So you've got to be careful. You've got a student newspaper, Wansolwara, that will be scrutinised and judged equally with the mainstream press. So what we can do is discuss things quite openly in panel discussions and in class and hope that nobody will go and talk about that outside the class. We can also set assignments, and we also push the envelope as much as possible with the student publications, but there is a line we will not cross, and that is the situation. And that is the situation post the 2006 coup. Prior to the coup, we could speak 
freely without fear of being jailed or being fined in a big way or that sort of thing, so that's the big difference.

FUIMAONO TUISAU: Are you hopeful, Alex?

ALEXANDER RHEENEY: Well, the media in Papua New Guinea have played a really big role over the years, over the last 40 plus years, since Papua New Guinea became a sovereign nation in 1975 . There have actually been attempts to actually 'regulate' the media before, and the last time it happened there was a big public outcry, and Papua New Guineans actually took to the streets to hold demonstrations against the government trying to censor or regulate. I think now with social media Papua New Guineans are educating themselves and informing themselves on the benefits of joining the conversation but also expressing themselves. And they now know that using the media, either traditional or social, gives them a platform to enable that conversation to take place. I have this feeling that there would be a lot of criticism, there would be a protest if the government decides to go down the path that Fiji has gone down.

FUIMAONO TUIASAU: As an observer of Pacific-New Zealand relationships, there has been this belief that young Pacific leaders come to universities in New Zealand or Australia to get their academic training and work skills so they can take these back to the country to improve their development, business, commerce, academic work and even with the media outlets. But has that happened? Because what you're describing is almost like they're going into a sealed chamber where they can do all their business but in terms of expressing their own personal views or public views about matters that are happening in their country, which they are very well versed to comment on, they risk suffering sanctions.

KALAFI MOALA: I want to respond with something that is very, very important-just because we are going through struggles now with our democracy, it doesn't mean that democracy is not a good system to follow. There are principles in the leadership that need to be there. We're like a boat that has hit a storm or a hurricane, and we just need to manage and adapt and adjust to that. If you think this storm that we are experiencing will have us go back to the thing of the past, that we are now going to go back to the 'rulership' that we had - no, that's not going to happen. We already left the dock, we're already on our way to the future, we've just got to manage the storm that we're in. But I think that some of the messages that are coming through is that we need to make adaptations in the lives of leaders. It's a current issue with a lot of things that we deal with. It wasn't until I got to be operating within the Prime Minister's Office that I saw that a lot of it is a character issue. They don't really follow democratic 
principles like we know them. So I think the issue that we are going through in Tonga is a matter of calming down, there's a vote of no confidence going in against this government. This government has been in office just two years and the prime minister will not run again. So we've just got to be patient, manage things and hope that better things will be in the future. Maybe another good suggestion is to exchange prime ministers. We'd like some of the other prime ministers from the islands to come to our island!

QUESTION FROM AUDIENCE: I think that's important because as you know there's a growing Pacific population, young people born growing up in New Zealand, who are also on a journey of finding their identity and part of that is encouraging them to come back, encouraging them to be interested in what's happening. And unless that message of hope is provided to them, many of these will wash their hands and say, 'that's not my country, if that's the case'.

KALAFI MOALA: And that's why I mentioned before, it's this whole thing of 'who do you belong to'? So many great Tongan people overseas-very qualified who are willing to come back to Tonga to serve the country - but the question normally asked of them is, 'which side are you on?' And we're wanting to move the country to a place where it doesn't really matter whether you are a Republican or a Democrat, or Labour or National - we need good people with good governance who are able to come in and be the new leadership. And that's the process we are going through, and we're hoping it's going to be over soon.

QUESTION FROM AUDIENCE: Shailendra has called for a need for more investigative journalism, and that comes out of every institution that is in this room and in this conference. My question to you Kalafi as a veteran in the region, would you position yourself, being a young graduate coming out of an institution, would you position yourself to take the lead in ensuring that young graduates ask the hard questions of the leaders. Because at the end of the day it's about our role as media practitioners to bring those stories out.

KALAFI MOALA: Yes, very much. Of course, I personally believe that all journalism is investigative-you've got to investigate. Investigative journalism is not just another section that when you feel like it you get into it. Every story must be investigated. And so I really believe in that. I think there are other factors that we deal with today, the emerging journalism, and one another gentleman referred to. There's no problem in 'discipling' so-called, and letting them follow through, but the very important factor of the day is that they've got to be paid. And the wage of the day and the needs of the day are so very different from when we were starting out as pioneers. We could go in there and write 
stories and because it's our own organisation if there's not enough money we don't get paid but you keep going. Today we have much more educated young journalists that are emerging. I must say, though, they are less passionate about the issues than when we were growing up, and they are demanding high wages. Probably they deserve that, but the island organisations in our region, especially in Tonga, don't have that. We have so many good Tongan journalists who are trained, but they are working for the Australian High Commissioner, for the Chinese High Commissioner, for the Japanese and so on, because they pay them well, and we can't pay them.

FUIMAONO TUIASAU: Can I ask you more regional question, it sort of follows up with the other question about hope, what is the status of the regional media bodies that gather and support each other and in fact tell each other stories which the writer can't tell in their own countries? I'm familiar with the Pacific Islands News Association-PACNEWS (PINA) (n.d.).

ALEXANDER RHEENEY: Well, I've been in conversations and interactions with PINA. There is a lot happening behind the scenes. PINA had a regional summit for all island media organisations, I think two months ago, so it does happen. There is training that they get to roll out at their summits that they hold for media organisations. I think the key is being a member of PINA in order to benefit from the training that they provide.

FUIMAONO TUIASAU: So there is some regional... so you've had a long view of these regional bodies, Kalafi, what do you think?

KALAFI MOALA: I think there's been a decline, a very significant decline in the role that is played by the regional bodies. We've got PINA and it's not like it was in the 1970s, 1980s and 1990s. We've got a new organisation that I helped found called, PasiMA (Pasifika Media Association) (n.d.). It's great, we have documentation of what we are going to do; we haven't met for three years! But, of course, you've got your own PIMA (Pacific Islands Media Association) (n.d.) here in New Zealand, which I was the founding chairman of for some time. So when you look at the region, the lead organisations, there has been a huge decline, and you start asking what the role is. Whether this means we need new organisations, I don't know, but I think this is a role where the journalism schools will play a major part. The journalism schools will become the forum where a lot of not only training but also where you congregate, like David Robie has done here with the Pacific Media Centre. They do a lot of things that media associations should be doing but are not doing. So maybe there is a shift here and emphasis on creating new forums, like Misa Vicky Lepou in 
Samoa, Shailendra Singh in USP, and then the University of Papua New Guinea (UPNG) and then here in Auckland with what's happening here.

FUIMAONO TUIASAU: I'll leave the last word with you then we'll wrap up.

DR SHAILENDRA SINGH: Just very quickly about regional media organisations in the Pacific, they're quite rudimentary outfits. I think in recent times the funding has dried up even more, and if you look at PINA, for example, it's run by only two people, and they're already overloaded with quite a bit of work. And I think what Kalafi said about tertiary education and also media educators playing an important role, yes we can step in and hold media summits, conferences and also research, so that's a possibility of providing training. One last thing I want to say about Fiji, it's not that in Fiji you can't criticise the government. The government is becoming more tolerant of criticism as time goes on. Fiji's case is very complex, it's not like New Zealand or Australia, and I think some of the population is recognising that democracy in Fiji is not an event, but a long process, and a painful one. So some people are a bit more patient than others and we don't forget that this current government was voted in by a 60 percent margin. So some people, it would seem, even if we just passed a history of instability, corruption and all those sorts of things, they possibly prefer a strong centre or maybe a benevolent dictatorship. So that's the observation.

FUIMAONO TUIASAU: Thank you. I'm going call on the Pacific Media Centre's Advisory Board chair Associate Professor Camille Nakhid to report back to us on some of the themes that she's come across.

DR CAMILLE NAKHID: Thank you for trying to put this all together. Kalafi Moala spoke about reform and in spite of reforms that took place and have taken part in democracy, the corruption still continues, so it's not about governance, it's the people that are there under good leadership that is required. By stopping corruption, you can stop anti-corruption problems that we have, so we need to address that sort of corruption. Shailendra Singh looked at the fact that the corruption is a serious problem and it hinders opportunities to escape corruption in line with what Kalafi said, and it's responsible for the past four coups that have happened in the last 25 years, because coups are operated by a corrupt business. And politicians you said are not taking corruption seriously. So starting over some of the problems that we have in Fiji are newsrooms capacity, there are problems with investigative journalism - you've highlighted that - you need experienced investigative journalists to highlight the issues of corruption, because apparently corrupt politicians keep showing up.

Alexander Rheeney, you looked at mainstream media in Papua New Guinea 
and the challenges there including poverty, HIV, tuberculosis. You said journalists need to start asking the hard questions, and it is a hard task for journalists to do, to hold the government accountable. Social media, you pointed out, is a blessing because it gives you that freedom of expression, but probably not if they are going to be taking and arresting young people for being on social media. And you've cautioned that governments try to regulate media industries. So looking at all you have said and looking at the questions that have come from the audience, in terms of corruption and in terms of the media role and the fact that corruption doesn't seem to be stopping in any way, in fact it's growing, the question I ask to all of you is not 'what next', but I ask 'who is next? Which Pacific Island is next?' With the banning of the media and the control, that is a concern here for not just the media educators but to the citizenry in the Pacific countries.

\section{Resources}

Video 1: Pacific corruption 'like cancer' - presentations (Pacific Media Centre, 55m 50s) www.youtube.com/watch? $v=$ HycGQZDU1A0

Video 2: Pacific corruption 'like cancer' - discussion (Pacific Media Centre, 31m 08s) www.youtube.com/watch?v=KE3SO74q7Ow

\section{References}

Chenoweth, N. (2016, May 6). The Panama papers New Zealand link revealed. Stuff. Retrieved from www.stuff.co.nz/business/79714914/The-Panama-Papers-NewZealand-link-revealed

Corruption Perceptions Index (n.d.). Transparency International. Retrieved from www. transparency.org/research/cpi/overview

Discarding democracy: Return to the iron fist (2015). Freedom on the World 2015. Freedom House. Retrieved from https://freedomhouse.org/report/freedom-world/ freedom-world-2015

Fiji Independent Commission Against Corruption (n.d.). FICAC website. Retrieved at www.ficac.org.fj

Former Tuvalu PM to serve jail term on weekends (2016, June 29). Radio NZ International. Retrieved from www.radionz.co.nz/international/pacific-news/307492/ former-tuvalu-pm-to-serve-jail-term-on-weekends

Gonschor, L. (2016). French Polynesia. The Contemporary Pacific, 28(1), 210-220. DOI: $10.1353 / \mathrm{cp} .2016 .0025$

Matasororo, E. (2016). Standoff in Papua New Guinea: Students take issue over corruption. Pacific Journalism Review, 22(2), 13-19. DOI: http://dx.doi.org/10.24135/pjr.v22i2.71

Media Industry Development Decree 2010 (2010). Republic of Fiji Government. Decree No. 29 of 2010. Retrieved from http://www.pmc.aut.ac.nz/sites/default/files/file_bin/201409/ Decree-29---Media-Industry-Development-Decree.pdf

Moala, K. (2016, April 22). Tonga's 'transparency' prime minister violates media freedom over questions. Asia Pacific Report. Retrieved from https://asiapacificreport.nz/2016/04/22/ tongas-transparency-prime-minister-violates-media-freedom-over-questions/

Pacific Islands Media Association (PIMA) (n.d.). Available at www.pima.org.nz

Pacific Islands News Association (PINA) (n.d.). Available at www.pina.com.fj 
Papua New Guinea prime minister served with arrest warrant (2014, June 16). The Guardian. Retrieved from www.theguardian.com/world/2014/jun/16/papua-newguinea-prime-minister-served-with-arrest-warrant

Pasifika Media Association (PasiMA) (n.d.). Available at http://pacific-media.org/

PNG Supreme Court orders PM to face no-confidence vote after riots (2016, July 13). Māori Television News. Retrieved from www.maoritelevision.com/news/latest-news/ png-supreme-court-orders-pm-face-no-confidence-vote-after-riots

Shewan, J. (2016). Government inquiry into foreign trust disclosure rules. Wellington, New Zealand Government, May 2016. Retrieved from www.treasury.govt.nz/publications/ reviews-consultation/foreign-trust-disclosure-rules/pdfs/report-giftdr-27jun2016.pdf

Tahiti court gives Flosse jail sentence for corruption (2013, January 16). Radio NZ International. Retrieved from www.radionz.co.nz/international/pacific-news/209642/ tahiti-court-gives-flosse-jail-sentence-for-corruption

Vanuatu court sentences MPs, including former PMs Carcasses and Vohor, to jail for corruption (2015, October 24). ABC News. Retrieved from www.abc.net.au/news/201510-22/vanuatu-mps-including-moana-carcasses-and-serge-vohor-sentenced/6875566

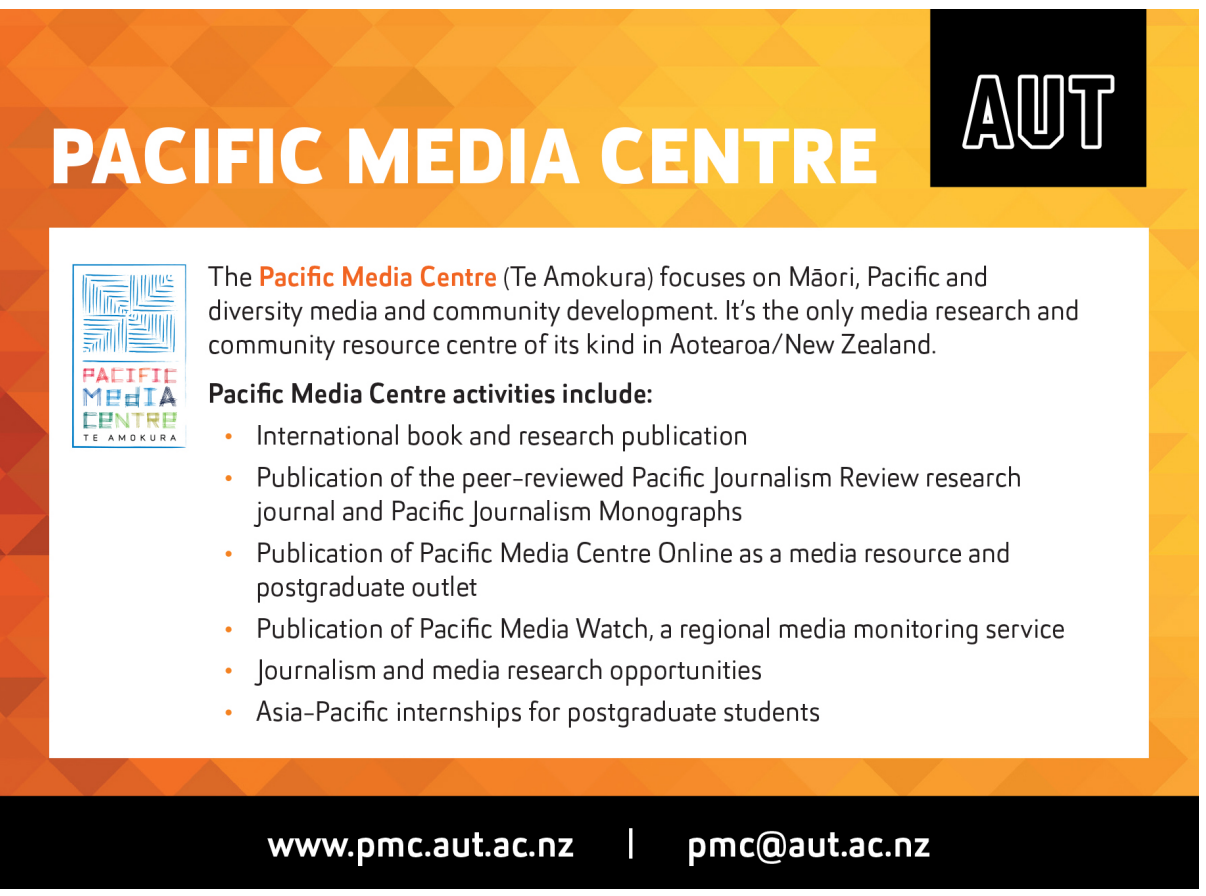

